\title{
Earthquakes in Greenland
}

\author{
SØREN GREGERSEN
}

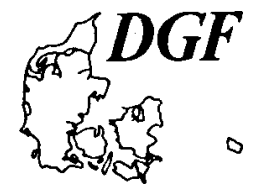

Gregersen, S.: Earthquakes in Greenland. Bull. geol. Soc. Denmark, vol. 31, pp. 11-27.

Copenhagen, November 15th, 1982. https://doi.org/10.37570/bgsd-1982-31-02

Data on earthquakes in Greenland from the international and Canadian seismological bulletins have been checked against the seismograms of the seismological stations in Greenland. A few new earthquakes have also been located based on seismograms from Greenland and Canada. A total of 103 reliable earthquakes have been confirmed, located and relocated. The earthquakes occur mainly along the coasts of eastern, northern and western Greenland. The largest earthquakes in Greenland have magnitudes around 5. There is no tectonic plate boundary in Greenland. The intraplate earthquake zones in north-eastern and in northern Greenland are situated as linear continuations of the plate boundaries near the bend of the mid ocean ridge close to Station Nord, between Spitzbergen and Greenland.

Under the ice cap only a few earthquakes have occurred. In eastern and in northern Greenland a few swarms of earthquakes have been found. In western Greenland a sequence of seismic signals is noticed at a distance of $175 \mathrm{~km}$ from Godhavn. Its origin may be small earthquakes. The time sequence of the earthquakes in Greenland shows two time intervals of increased earthquake activity after the two largest earthquakes. This indicates that stress adjustments in the largest earthquakes give rise to stress adjustments in the smaller earthquakes more than $1000 \mathrm{~km}$ away, in other parts of Greenland. There is only limited correlation between earthquake activity and surface geology. It can not be determined whether the main cause of the intraplate earthquakes in Greenland is isostatic uplift following the latest ice age or tectonic plate motion in connection with sea floor spreading in the Norwegian-Greenland Sea and in the Arctic Ocean.

Søren Gregersen, Geodetic Institute, Gamlehave Alle 22, DK-2920 Charlottenlund, Denmark. February 18 th, 1982.

\section{Introduction}

Until recently Greenland has been considered almost free of earthquakes, since just a few earthquake locations have fallen within Greenland in investigations, of which Greenland was a part. This is seen in the papers by Linden (1961) and by Hodgson et al. (1965), concerned with the special effort to locate earthquakes in the Arctic region during the International Geophysical Year and the following few years. Voronov \& Klushin (1963) concluded from the lack of earthquakes in Antarctica and Greenland, that plastic deformations were occurring. Sykes (1965) relocated a number of earthquakes in the Arctic region and found only eight earthquakes in Greenland in the period 1955 to 1964.

The reason, that so few earthquakes were found, was the poor sensitivity to local earthquakes of the few seismological stations in Greenland, and the long distance between Greenland and other seismological stations. Table 1 gives a description of the development of seismological instrumentation in Greenland. The first permanent stations in Greenland were set up for recording of the largest earthquakes on the earth, while the newer permanent seismological stations are equipped with instruments designed for recording of large distant earthquakes as well as of smaller earthquakes nearby. In northern Canada a network of seismological stations was developed during the 1960s (Basham et al. 1977 a). This has also improved the sensitivety to small earthquakes in Greenland. The installation of new instruments in Greenland and in northern Canada coincided with improvements in the international data exchange and in the location procedure by the establishment of the International Seismological Centre (ISC) in 1964.

Husebye et al. (1975) have reported on the seismicity in the Norwegian-Greenland Sea and adjacent continental areas. In eastern Greenland they knew of nearly 20 earthquakes in the period 1955-1972. They speculated, that the most active seismicity zone in north-eastern Greenland and a seismicity zone in northern Norway could be related to a common zone of weakness, which had developed before sea floor spreading started in the Norwegian-Greenland Sea.

Vogt (1978) on the other hand suggested that 
Table 1. Time development of the seismological instrumentation in Greenland. $\mathrm{Z}$ is up-down, $\mathrm{N}$ is north-south, $\mathrm{E}$ is east-west. Note the improved sensitivity to local earthquakes with time.

\begin{tabular}{|c|c|c|c|c|c|}
\hline \multirow[t]{2}{*}{ Location } & \multirow[t]{2}{*}{ Seismographs } & \multirow[t]{2}{*}{ Operation period } & \multicolumn{3}{|c|}{$\begin{array}{l}\text { Sensitivity to local } \\
\text { earthquakes }\end{array}$} \\
\hline & & & Good & Fair & Poor \\
\hline Godhavn & Bosch N, E & 1907-1912 & & & $\mathbf{x}$ \\
\hline \multirow[t]{2}{*}{ Ivigtut } & Wiechert Z, N, E & $1929-1953$ & & & $\mathbf{x}$ \\
\hline & Milne-Shaw N & $1955-1960$ & & & $\mathbf{x}$ \\
\hline \multirow[t]{4}{*}{ Scoresbysund } & Galitzin-Wilip Z, N, E & 1928-1964 & & & $\mathbf{x}$ \\
\hline & Grenet $\mathrm{Z}$ & $1950-1964$ & & $\mathrm{x}$ & \\
\hline & Press-Ewing Z & $1982-$ & & & $\mathbf{x}$ \\
\hline & S-13 Z & $1982-$ & & $\mathbf{x}$ & \\
\hline \multirow[t]{4}{*}{ Station Nord } & Wilmore Z & $1957-1963$ & & $\mathrm{x}$ & \\
\hline & Strobach N, E & $1957-1963$ & & & $\mathbf{x}$ \\
\hline & WWNSS Z, N, E & 1963-1972 & & $x$ & \\
\hline & S-13, MEQ-800 Z & 21/3-12/6 1979 & $\mathbf{x}$ & & \\
\hline Godhavn & WWNSS Z, N, E & 1962-present & & $\mathrm{x}$ & \\
\hline Kap Tobin & WWNSS Z, N, E & $1963-1980$ & & $\mathrm{x}$ & \\
\hline \multicolumn{6}{|l|}{ Inge Lehmann } \\
\hline $\begin{array}{l}\text { station Array } \\
\text { Danmarkshavn }\end{array}$ & $\begin{array}{l}\text { Geotech-system Z } \\
\text { WWNSS Z, N, E }\end{array}$ & $\begin{array}{l}\text { AUG 1966-AUG 1967 } \\
\text { 1972-present }\end{array}$ & $\mathbf{x}$ & $\mathbf{x}$ & \\
\hline \multirow{2}{*}{ Søndre Strømfjord } & S-13, MEQ-800 Z & $6-9 / 51976$ & $\mathbf{x}$ & & \\
\hline & & $15 / 4-9 / 5 \quad 1977$ & $x$ & & \\
\hline Upernavik & S-13, MEQ-800 Z & $29 / 7-6 / 101978$ & $\mathbf{x}$ & & \\
\hline
\end{tabular}

the general pattern of the seismicity in the Norwegian-Greenland Sea and adjacent regions should all be connected to upwelling of mantle material under Iceland and outward flow in a broad area around this upwelling. Vogt argued that the area of maximum outward flow seems to have high interplate as well as intraplate seismicity. Northern and north eastern Greenland is in Vogt's classification in the area of relatively high intraplate seismicity.

The seismicity of northern Canada has been investigated by Basham et al. (1977 a). They note that the seismicity near the continental margin of Baffin Island is located in an area, where the gradient of the uplift velocity of northern Canada is large, such that Canada south west of the seismicity area is still isostatically uplifted after the latest ice age, while Baffin Bay and Greenland is not uplifted.

In recent years the seismological bulletins of the Earth Physics Branch in Canada (e.g. Horner et al. $1979 \mathrm{~b}$ ) have included a number of earthquakes in Greenland. These as well as the earthquake locations determined by the various international seismological agencies were included in a seismicity map of the Arctic region, which displayed 80-90 earthquake locations in Greenland (Wetmiller \& Forsyth 1978). The same sources of data have been used in the present paper, the difference being that every intraplate earthquake in and close to Greenland has been checked against the records of the Greenland seismological stations, and some nonexistent "ghost" earthquakes and very inaccurately determined earthquakes were not included in the seismicity map of the present investigation. On the other hand a few earthquakes were added, which were recognized from the seismological stations in Greenland. In the period 1940-1978 102 earthquakes have been accepted as reliable in the present investigation.

\section{Earthquake locations}

Data sources on recent earthquakes in or near Greenland are the International Seismological Centre (ISC) (monthly bulletins since 1964) and the Earth Physics Branch publication series "Canadian Earthquakes" (Stevens et al. 1972, 1973, 1976, Horner et al. 1974, 1975, 1976, Basham et al. 1977 b, Wetmiller 1976 a, 1976 b, 1977, Wetmiller \& Horner 1978, Horner et al. 1979 a, 1979 b). For the period before 1964 a number of sources have been searched: Historical seismicity tapes of the ISC and of United States Geological Survey as well as the papers by Sykes (1965), Linden (1961) and Hodgson et al. (1965). 
Every earthquake suggested by one of these seismological sources to be in or near Greenland has been reviewed in the bulletins, and the records at the seismological stations in Greenland (table 1) have been checked. For the new earthquakes, 1964-1978, confirmation at one Greenland station has been considered enough for acceptance of an earthquake for the seismicity map (fig. 1), if its location is based on readings from at least 4 stations altogether. Confirmation by the records of at least two of the checked Greenland stations was required when only readings at 3 stations altogether were available for the location. No earthquake locations have been accepted for fig. 1 with readings from only 2 stations available. Before the improvement of the seismological station network in Greenland and in northern Canada, i.e. until 1963, earthquakes have only been accepted, if they have been confirmed in the records of at least one Greenland station, if the location was based on readings from at least 10 stations and if these 10 stations were not all within a small angle of azimuth from the earthquake.

For some earthquakes new readings of seismological wave arrivals became available, which were not used in the location by the seismological agency reporting the earthquake. These earthquakes have been relocated. Additionally 11 earthquakes, which had not been suggested by any agency previously, have been located, based on all available readings from Greenland and northern Canada.

In the review process 2 nonexistent "ghost" earthquakes have been thrown out, and two other categories of earthquakes have not been accepted for fig. 1 a) 23 earthquakes, especially close to Station Nord, have been judged to be slightly mislocated from the surrounding seismic zones, denoted by grey shading in fig. $1 \mathrm{~b}$ ) 32 earthquakes which have probably happened in Greenland, especially in northern Greenland, were not accepted for fig. 1 by the mentioned criteria. Their locations are considered to be more uncertain than those of fig. 1 , so that fig. 1 gives a better impression of the earthquake geography than a map with the full data set. The events, which are not accepted, are in the magnitude range below $3^{1 / 2}$, where the earthquake observations are not complete with the present network of seismological stations.
The resulting seismicity map (fig. 1) gives a much clearer picture of the zones of seismicity in Greenland than that reached by previous summaries of the seismicity in maps, where Greenland was included (Sykes 1965, Barazangi \& Dorman 1969, Wetmiller \& Forsyth 1978).

The magnitudes of the earthquakes in Greenland are determined in two different but consistent ways as described by Gregersen (1982). The International Seismological Centre has determined $m_{b}$ magnitudes for 12 of the largest earthquakes. A local magnitude scale base on amplitude readings of the largest arrival on the Greenland records, the $\mathrm{Lg}$ wave arrival, has been applied to all of those earthquakes, where a $\mathrm{Lg}$ wave amplitude reading is available.

The largest earthquakes in most of Greenland have magnitudes around 4 , but in any of the seismic zones in north eastern, northern, western and southern Greenland there is one or a few earthquakes of magnitudes around 5 . In north eastern Greenland the largest earthquake is in the middle of the seismic zone between the stations Nord and Danmarkshavn. In the north the largest earthquake is the one off shore closest to the mid ocean ridge (fig. 1). Near the seismological station Kap Tobin a few earthquakes have magnitudes nearly 5 , and the southernmost earthquake on land in Greenland has magnitude $4 \frac{1}{2}$. In western Greenland the largest earthquakes were until recently expected to have magnitude a little over 4 , but an earthquake near Thule, in the northern part of the western Greenland zone, JAN 4 1981, had a magnitude of $43 / 4$ (fig. 1 ).

The depths of the earthquakes in Greenland can not be determined accurately. For the largest earthquakes, for which a number of seismological station readings are available at large distances as well as at short distances the computations give shallow depths, within the crust or the uppermost mantle. Most of the earthquakes are judged to be shallow, just as the larger events, because the seismograms contain more than one $\mathbf{P}$ arrival at least at one seismological station.

The present compilation in fig. 1 has been confined to the area between the earthquake zones in the Arctic Ocean, the North Atlantic, Labrador Sea, northern Canada and Baffin Bay (see names in fig. 2). The seismicity of these seismic zones and the area outside has been investigated by 


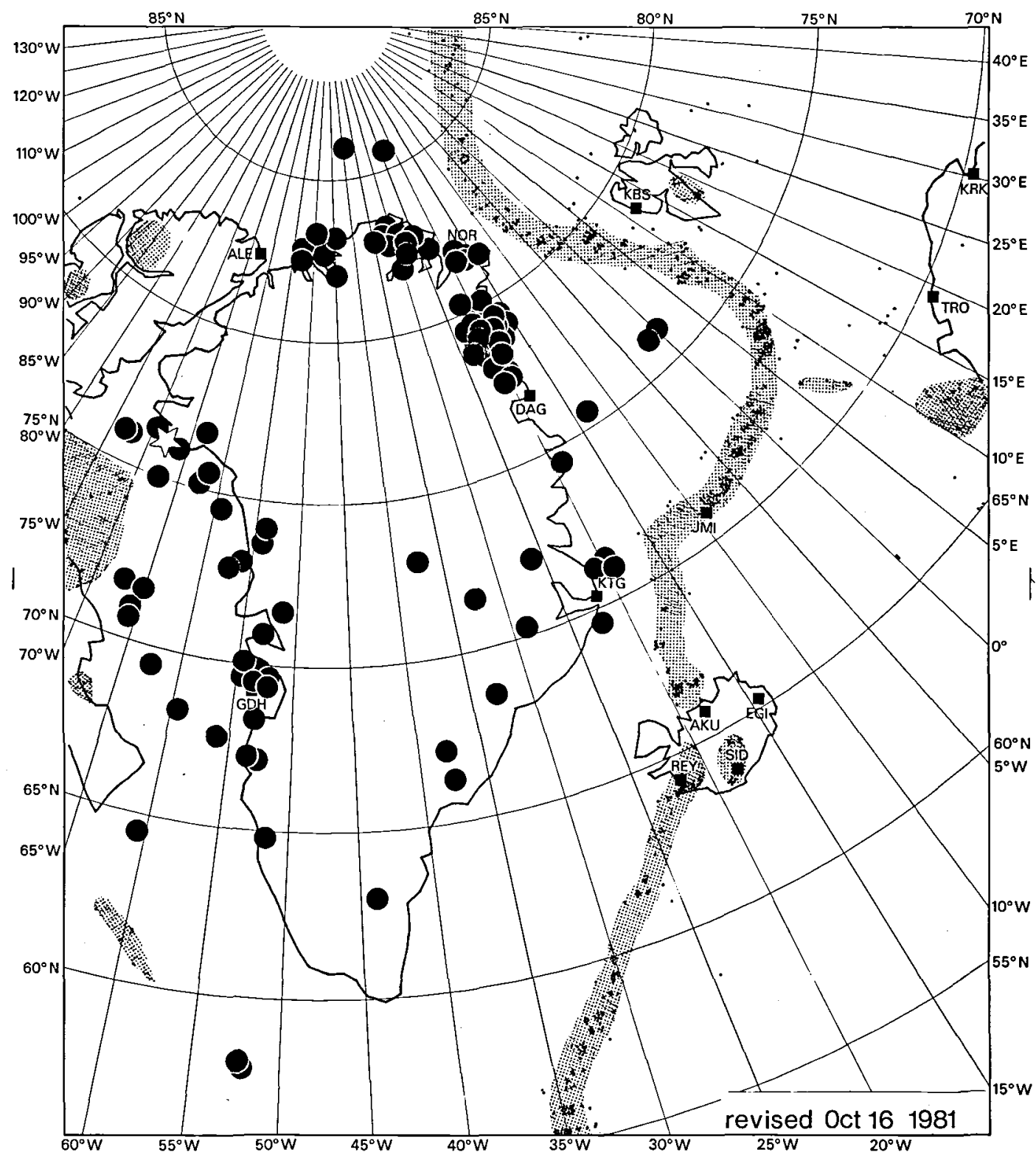

Fig. 1. Earthquake locations 1940-1978. Large dots are reliable earthquakes. Grey small-dotted areas and small sigle dots are zones of earthquakes and single earthquakes accepted from other authors. Star is location of the earthquake JAN 4 1981. Squares with three letter codes are seismological stations.

other authors as follows. The seismic zone through the Arctic Ocean, the North Atlantic and Iceland is a plate boundary between the American and the European plates (Husebye et al. 1975, Klein et al. 1973). The seismicity in the Labrador Sea and in Baffin Bay may be connected to the old plate boundary between
Greenland and Canada (Kristoffersen \& Talwani 1977, Qamar 1974, Keen et al. 1972). The Canadian seismic zones have bee treated by Basham et al. (1977 a) and by Stein et al (1979). The plate boundary in the Arctic Ocean and in the North Atlantic Ocean and the largest seismic zone in northern Canada (fig. 1) are much more 


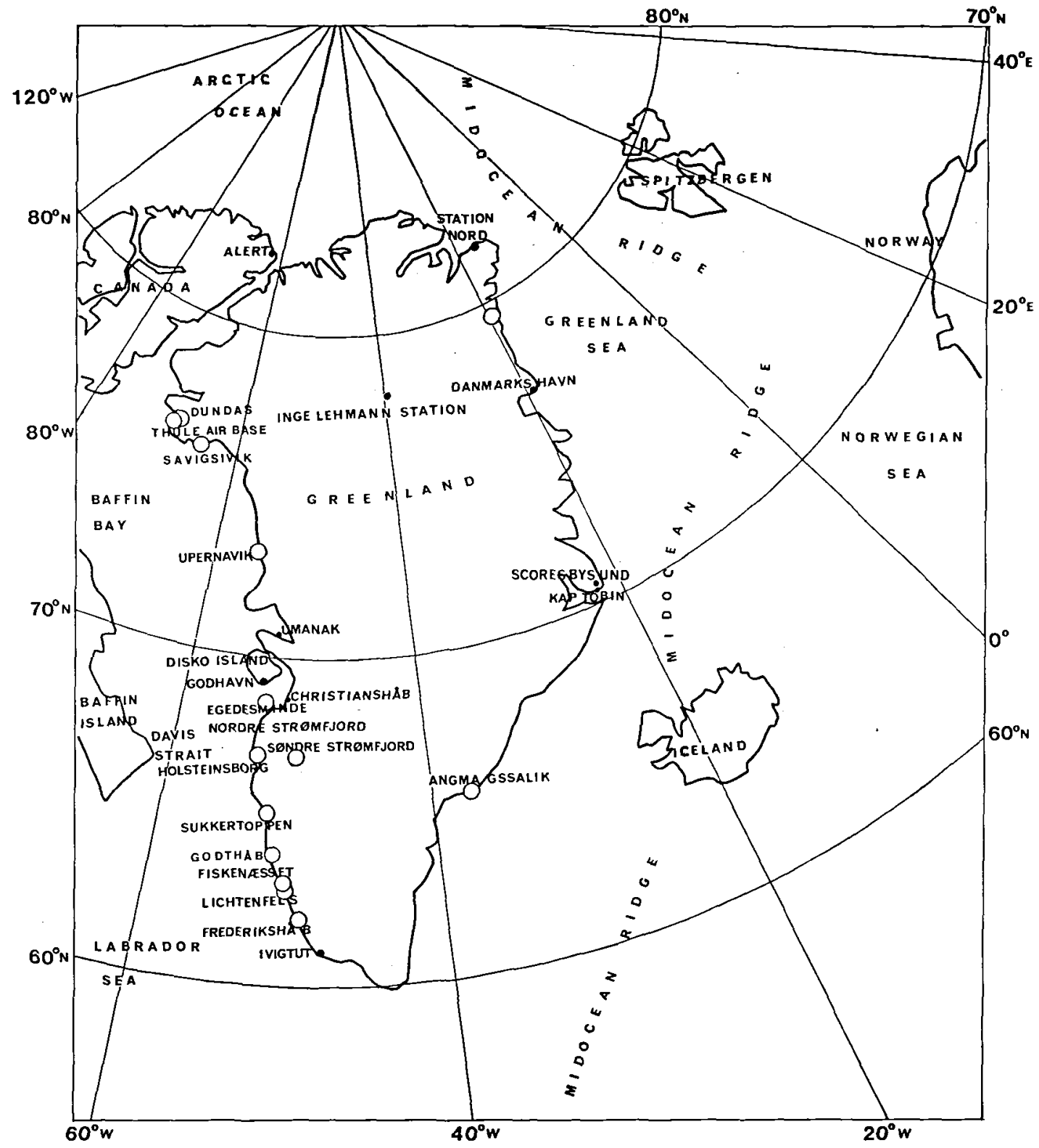

Fig. 2. Location of felt earthquakes - open circles. Names mentioned in text.

active and have larger earthquakes than Greenland, while the activity in the smaller seismic zones in northern Canada and near northern Norway is similar to that in Greenland.

The projection chosen for the map of fig. 1 is such that a straight line through station Nord (NOR) is a great circle on the earth. In fig. 1 it is seen that straight lines may be drawn through the seismic zones in north eastern and in northern Greenland and the plate boundaries in the Arctic Ocean and in the northern Norwegian-Greenland Sea respectively.

Along the west coast of Greenland there is a seismic zone (fig. 1). It crosses Melville Bay, the eastern part of Baffin Bay, rather than follow the coastline in the northernmost part of the zone. 
There is a concentration of earthquakes in Disko Island near the seismological station GDH. Naturally the closeness of a seismological station gives good sensitivity to these earthquakes. Whether concentrations would be detected in other areas, if instruments were placed there, is uncertain.

It is noteworthy that there is no connection between the seismic zones in northern and western Greenland. In fig. 1 there is no seismicity in the straits and sounds SW of the seismological station ALE, called the Nares Strait. The lack of earthquakes along Nares Strait is also pointed out by Wetmiller \& Forsyth (1982).

The smallest earthquake plotted in fig. 1 is the one farthest from the coast, on land. Its magnitude is $2 \frac{1 / 2}{2}$. It was detected and located during a short project, when a portable seismograph was placed in Søndre Strømfjord (table 1). The signals from it are small but distinguishable on the records from all the Greenland stations and from two Canadian stations. Other earthquakes of the same small size may occur in other locations, although they are not found in the routine processing of the records.

\section{Earthquakes felt in Greenland}

Reports of felt earthquakes are collected in the Department of Seismology of the Danish Geodetic Institute. A few of the earthquakes in fig. 1 have been felt by the local population or by people travelling. This is true for an earthquake in each of the following locations: Holsteinsborg, Egedesminde, north east Greenland, and the Thule area (fig. 2).

From Holsteinsborg reports of felt earthquakes are available for earthquakes in 1938, 1944, 1946, 1971, 1975, 1978 and 1979. The earthquakes have been felt by almost everybody in Holsteinsborg, a town of nearly four thousand inhabitants, and that 15 AUG 1979 by two people in Søndre Strømfjord as well. No damage has occurred. Many of the earthquakes have had rumblings or explosionlike sound associated with them. Some of the reports have mentioned 2 or 3 earthquakes within a few hours. An old diary by the missionary Glahn (1921) contains short reports of earthquakes in $1762,1763,1767$, and
1768. With one of these a hissing sound was heard. Giesecke (1910) in his diary of the year 1807 claims, that almost each year an earthquake is felt in Holsteinsborg, although he did not feel on himself. Harboe (1910) has quoted reports of an earthquake JAN 261907 in Holsteinsborg, mentioning a strong, abrupt shock, and a rattling sound in the earth. The sea ice cracked and the ice free sea surface moved vigorously. The earthquake was felt in only one of the nearby small settlements about $10 \mathrm{~km}$ east of Holsteinsborg, and there it was stronger than in Holsteinsborg.

The earthquake near Egedesminde was felt by many people in the town of more than three thousand inhabitants, in 1975. Locally it is said that earthquakes have been felt previously in this area, but only one report exists besides this one. MAY $1919081^{\text {h } 24^{\mathrm{m}} 27^{\mathrm{s}}}$ GMT local earthquake signals were recorded on the seismographs in Godhavn. Harboe (1910) has reported that the earthquake was felt in a number of settlements on the coasts of the Disko Bay, south of Disko. In some of the reports of this earthquake hissing sounds are mentioned, and in a report from Christianshåb a rock slide is mentioned at a time within an hour of the time of the earthquake. In Godhavn shaking has been reported earlier, in Giesecke's (1910) diary for FEB 2 1811. He suggests that the cause may have been a rockslide.

One of the earthquakes of the cluster in north eastern Greenland (fig. 1) has been felt by two men in a tent. They reported a thunderlike sound and shaking of the sea ice reminding them of sea wave motion. The position of this observation was $79^{\circ} .27 \mathrm{~N} 19^{\circ} .33 \mathrm{~W}$, while the epicenter of the earthquake determined by the International Seismological Centre is $79^{\circ} .02 \mathrm{~N} 19^{\circ} .9 \mathrm{~W}$ based on readings from 27 seismological stations. The distance between those two points is only $30 \mathrm{~km}$, and the $\mathrm{m}_{\mathrm{b}}$ magnitude of the earthquake is 4.2. The near coincidence indicates that the larger earthquakes, as this one, are not systematically mislocated in north eastern Greenland, even if there are few local stations.

For the earthquake JAN 41981 marked by a star in fig. 1 reports are available from 3 locations: Dundas, Thule Air Base (also nearby J-site and P-mountain) and Savigsivik (fig. 2). The reports mention shaking from side to side, rattling sounds in the houses, and some people have 
heard a rumbling sound from the earth or from the sea ice. Some small cracks, like "melt water cracks", opened in a road in Thule Air Base, and near Savigsivik a rock slide occurred. The distance between Savigsivik and Dundas/Thule Air Base is $120 \mathrm{~km}$. The instrumental location of the earthquake is near the middle point between these places.

Two earthquakes of fig. 1 are close to Angmagssalik. None of these two have been reported felt. But a lot of other earthquakes have been felt in Angmagssalik. For some years there are more than ten reports of earthquakes. Some of the reports describe a number of events within a few hours or days. Some reports describe thunderlike or hissing sounds in connection with the earthquakes. Since 1937112 earthquakes have been reported to the Department of Seismology of the Danish Geodetic Institute. Before that time a number of old reports mention earthquakes in Angmagssalik. At least 11 earthquakes occurred in the time period 1894 to 1904 (Rüttel 1917). With two of these earthquakes thunderlike rumbling is mentioned. In 1904 there was a full day of shaking and rumbling on NOV 22, and apparently the seismic activity with some shaking nearly every day did not cease until MAR 11 1905 (Petersen \& Rosing 1905). JUL 9 and 10 1905 a few more earthquakes were felt in Angmagssalik. OCT 1819073 earthquakes with about 5 minutes between them were felt in Angmagssalik (Harboe 1910), and rumbling was heard in connection with the shaking. During the following night, OCT 18-19, a number of weak earthquakes were felt, and later, DEC 2 1907, MAY 27 1908, and NOV 11 1908, 3, 2, and 2 earthquakes occurred. Harboe (1915) claims: "The seismically most active area in Greenland seems to be Angmagssalik", and he reports on 7 earthquakes between MAR 30 and MAY 14 1913. The last two were heard. No reports are available from Angmagssalik for the time period 1913 to 1937.

Four earthquakes in fig. 1 are close to the town of Upernavik. None of these have been reported felt, but two older reports exist of earthquakes felt in Upernavik. No sounds have been reported in connection with the earthquakes in Upernavik. No local earthquakes were detected near Upernavik during a short field project in Upernavik in the summer of 1978 (table 1).
South of Holsteinsborg earthquakes have not been reported felt recently. But in a very old diary (Raben 1826) two earthquakes are reported. In 1811 one was felt in Fiskenæsset and Frederikshåb, and in 1823 one was felt in Fiskenæsset, Lichtenfels and Sukkertoppen. In connection with the latter earthquake a hissing sound was heard. In another old diary (Giesecke 1910) two other earthquakes are reported. JAN 21 1809 an earthquake was felt in Godthåb and in Lichtenfels, and APR 10 the same year one was felt in Godthåb again. Harboe (1910) reports that in 1907, NOV 25, an earthquake is said to have been felt and heard in Godthåb, and that an earthquake was felt in Fiskenæsset in 1909, OCT 5 (Harboe 1915).

\section{Other seismic events}

Many more seismic events that those in fig. 1 are recorded at one or two stations in Greenland and nowhere else. A large number of these are local disturbances in connection with local construction or heavy traffic, but another part of the seismic events are small earthquakes. For many of the events it is possible to read both a $P$ and an $S$ wave arrival, so that it is possible to sort this group of events according to the time between the two arrivals. This has been done for the available time periods for the seismological stations in Greenland: NOR, GDH, DAG, and KTG and almost similarly for the Canadian station ALE. The results of this sorting are presented in fig. 3.

For the station NOR it is seen that a few events happen very close to the station, with small S-P times. The author is told that the list of readings of very near events, with S-P times of less than several seconds, is not complete (Hjortenberg personal communication 1981). At S-P time 19-20 seconds there is a tremendous increase in the number of events. The interpretation is, that this large number of events are mainly earthquakes at the mid ocean ridge. The S-P time 19 seconds corresponds to a distance to this zone of approximately $170 \mathrm{~km}$ (fig. 1). The general trend of the number of earthquakes with larger S-P times in fig. 3 looks like an exponential fall off. As the S-P times become larger and larger the corresponding distances increase, and that means 

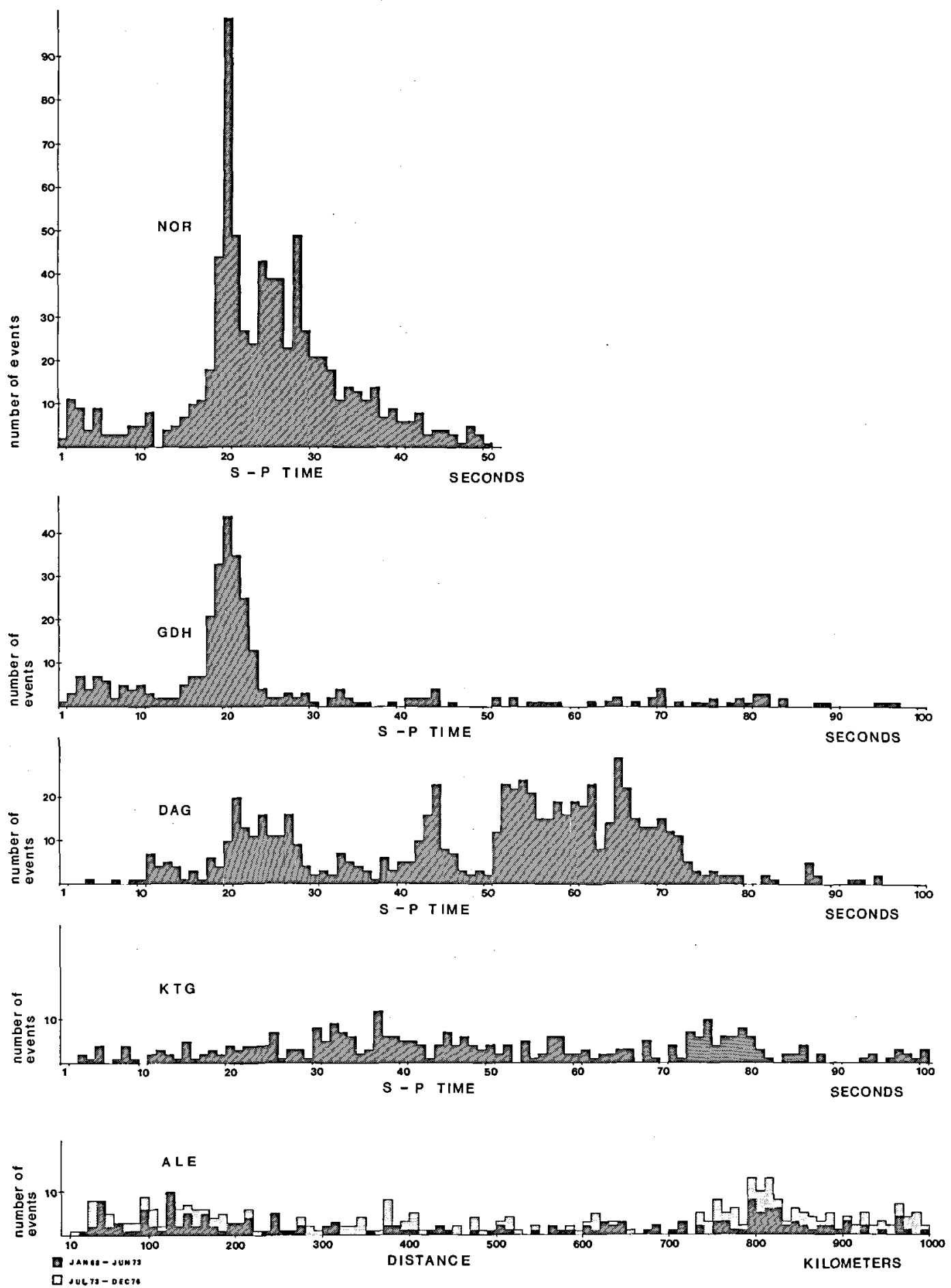

Fig. 3. Histogram of number of seismic events recorded at the seismological stations for each S-P time (or distance). Data periods: Station Nord (NOR) JAN 1959 - JUL 1963. Godhavn (GDH), Danmarkshavn (DAG), and Kap Tobin (KTG) JAN 1973 - APR 1977, Alert (ALE) JAN 1968 - DEC 1976. 
the station is only sensitive to larger magnitude earthquakes, of which there are fewer. The narrow highs and deeps in fig. 3 for NOR between 22 and 28 seconds S-P time correspond to more and less active parts of the mid ocean ridge. But the phenomenon may be time variable. In another $4 \frac{1}{2}$ year period the highs and deeps may be different.

For the station GDH there are some close events with S-P times between 3 and 10 seconds. They could be on Disko Island as some earthquakes in fig. 1. A much larger concentration of events is between 18 and 23 seconds S-P time. Since this corresponds to distances near $180 \mathrm{~km}$, the distance from Godhavn to Umanak, the location of the only active mine in Greenland, an explanation for some of the events could be sought in mining explosions. But the mining company reports that there is no correlation with the time sequence of the routinely read seismic events with these S-P times. 3 events out of the 171 events of the concentration in fig. 3 have been recorded also with a seismograph temporarily located in Søndre Strømfjord for a week in April 1977. The arrivals of the signals to the seismographs in Godhavn and in Søndre Stromfjord are simultaneous, so the source is located at equal distances from the two seismographs, under the edge of the ice cap south east of Christianshåb (see fig. 2 for names) or by the coast near Nordre Strømfjord. The events of the concentration occurred through the period JAN 1973 to APR 1977 with a few events almost every month, but with a special concentration of approximately 90 events in JAN-FEB 1974 . It is necessary to find the exact location of this still active concentration with use of more seismographs to establish, whether the events are earthquakes.

For DAG there are a number of concentrations of events in small ranges of S-P times. The events of the first concentration between 20 and 28 seconds are interpreted as smaller events in the seismically active area between Station Nord and Danmarkshavn (fig. 1). The events closer to Danmarkshavn, down to S-P time 11 seconds, probably come from the southern part of that same seismic zone. The concentration around 42,43 and 44 seconds S-P time was unexpected according to the seismicity map of fig. 1 . There is no concentration of earthquake activity at dis- tances between $300 \mathrm{~km}$ and $400 \mathrm{~km}$. Indeed, it was found that this concentration was the sign of a special earthquake phenomenon, an earthquake swarm, in which no earthquake was large enough to be located by the procedures used for fig. 1 (Gregersen 1979). The swarm lasted 9 days in 1974 from NOV 3 to NOV 11. The largest earthquakes of the swarm could be weakly distinguished also on the records at the station KTG. The swarm has been located from the records of the two stations, DAG and KTG, only. The loca-

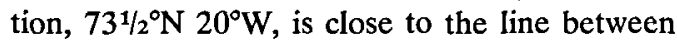
the two stations. The uncertainty is as large as $100 \mathrm{~km}$ in east west direction while it is $25 \mathrm{~km}$ in north south direction. For some of the earthquakes of this swarm the phase termed $S$ in the readings, which were the basis of fig. 3 , is actually the phase Lg. A careful second search through the seismograms revealed that the total number of earthquakes, which can be identified to be in the swarm, was 160 , more than twice the number of events of the concentration at 42-44 seconds in fig. 3. Another concentration of events at S-P times larger than 51 seconds corresponds to earthquakes at the mid ocean ridge from distances larger than $500 \mathrm{~km}$.

For the station KTG the number of earthquakes sorted in fig. 3. is quite small. There are no conspicuous peaks. The distance to the mid ocean ridge corresponds to $22-23$ seconds S-P time.

A figure similar to that for the stations in Greenland has been compiled for the seismological station Alert (ALE) from data in the publications "Canadian Earthquakes" (Stevens et al. 1976; Horner et al. 1974, 1975, 1976; Basham et al. 1977 b; Wetmiller 1976 a, 1976 b; Wetmiller \& Horner 1978). The scale of its horizontal axis is kilometers rather than seconds S-P time. The difference is small between the scales of the horizontal axes of the figures for ALE and for the other stations, since $10 \mathrm{~km}$ corresponds nearly to 1 second S-P time. Near Alert there are a number of rather local events. From a distance of $790 \mathrm{~km}$ the larger number of events is from the mid ocean ridge near Station Nord. The data for ALE was divided in two parts with dark and light signatures in fig 3. No systematic difference is obvious in the figure between the two time periods, each with approximately half of the earthquakes.

Additionally some swarms of earthquakes have 
occurred near Alert. A peak is missing in the ALE figure, namely around $240 \mathrm{~km}$. In the publications "Canadian Earthquakes" for 1967 and 1969 (Stevens et al. 1973, Horner et al. 1974) swarms of earthquakes are reported at that distance, and the statement is made (Stevens et al. 1973) that "similar swarms have been recorded frequently at ALE with a characteristic S-P interval of 28 seconds and amplitudes just above the noise level, indicating an epicentral distance of about $240 \mathrm{~km}$ and magnitudes about 2 ". One of these swarms, in 1967, has been located at

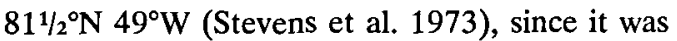
also recorded at the temporary seismological station Inge Lehmann (ILG) (table 1), and a number of the earthquakes of the swarm could be distinguished at Station Nord. The swarm lasted 5 hours on July 30 and contained 80 earthquakes (Gregersen 1979). It is not known how often short swarms occur at this location in northern Greenland, since the readings are not included in the data, which were used for the ALE curve of fig. 3. Only one swarm happened during the one year, when the station Inge Lehmann was in operation. It is assumed that the swarms at the same distance from ALE occur near the same location as the swarm of JUL 30 1967. Many earthquakes have also in recent years been observed with S-P times 28 seconds (R. J. Wetmiller, personal communication 1981).

\section{Time sequence of the earthquakes}

A histogram has been prepared describing the time sequence of the earthquakes of fig. 1, exclusive those in Baffin Bay near Canada, in Davis Strait and in Labrador Sea. The reason for the exclusion is that the cause of the seismicity there may be different from that in Greenland (Qamar 1974, Stein et al. 1979), and also that the earthquakes there are only partly included in the present investigation.

Only for the largest events of the period 1964-1978 the data set is sufficiently complete to define a time sequence (fig. 4). Below the histogram in fig. 4 the time sequence of the earthquakes is illustrated with the magnitudes of the earthquakes in the local magnitude scale $\mathbf{m}_{\mathbf{G}}$ (Gregersen 1982). There are two peaks in the histogram of fig. 4 in 1965-66 and 1972-76, and
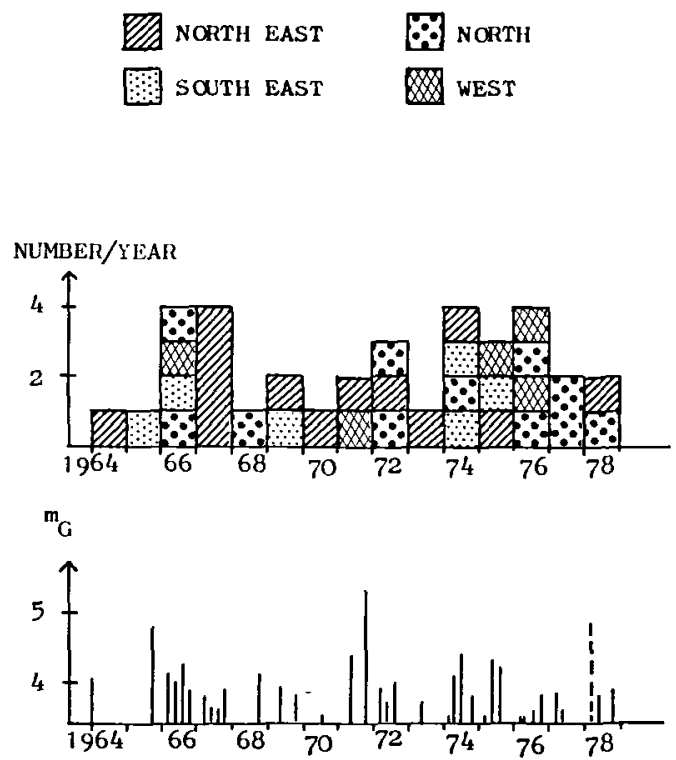

Fig. 4. Histogram of number of earthquakes in and near Greenland each year, exclusive the earthquakes in Baffin Bay near Canada, in Davis Starit and in Labrador Sea. $\mathrm{m}_{\mathrm{G}}$ is local Greenland magnitude (Gregersen 1982). Earthquakes with $m_{G}$ $\geqq 3.5$ included. Dashed line is earthquake JAN $41978250 \mathrm{~km}$ off the north coast of Greenland.

two earthquakes are noticed as the largest in Greenland in 1965 and 1971. The peaks follow after the largest earthquakes. It looks as if the smaller earthquakes could be aftershocks of the largest earthquakes. It is remarkable, that the aftershocks are anywhere in Greenland at distances up to more than $1000 \mathrm{~km}$ from the main shock. It may be suggested that Greenland acts as a stiff plate, where readjustment of stresses in one region gives rise to readjustment of stresses in another region $1000 \mathrm{~km}$ away. It remains to be seen whether the earthquake of JAN 1978 (dashed line in lower part of fig. 4) $250 \mathrm{~km}$ off the north coast of Greenland will be followed by an increase in the number of smaller earthquakes.

\section{Tectonic stresses}

The tectonic stress field in the earth's crust and upper mantle may be studied through in situ stress measurements and through fault plane solutions for earthquakes. Unfortunately no in situ stress measurements have been made in Greenland and only on fault plane solution is available 


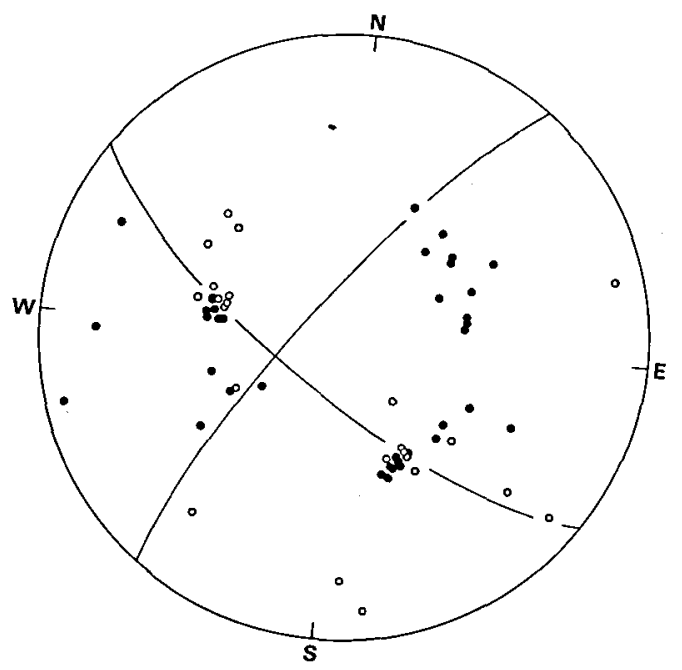

Fig. 5. Focal mechanism of the earthquake in the Arctic Ocean $86^{\circ} \mathrm{N} 24^{\circ} \mathrm{W}$ on JAN 4 1978. Full circles are compressions, open circles are dilatations. Equal area projection of lower focal sphere. Strike slip earthquake on a fault plane with strike $36^{\circ}$ and $\operatorname{dip} 80^{\circ} \mathrm{NW}$ or strike $124^{\circ}$ and $\operatorname{dip} 74^{\circ} \mathrm{SW}$.

in the literature (Sykes \& Sbar 1973), while a second one has just been determined by the present author simultaneously with Wetmiller \& Forsyth (1982).

The newly determined fault plane solution for the earthquake JAN 41978 north of Greenland is presented in fig. 5. It is based on the author's seismogram readings from Greenland, Canada, Norway and the World Wide Network of Standard Seismographs (WWNSS) supplemented with first motion reports from other stations in the monthly bulletin of the International Seismological Centre. The fault plane is one of the two planes denoted by the curved-line projections in fig. 5, which separate the quadrants with first-motion compression from those with dilatations. Wetmiller \& Forsyth (1982) base their fault plane solution on partly different sources, but their solution is almost the same.

The other earthquake in Greenland, which has been large enough for determination of a fault plane solution, is an earthquake in northeast Greenland near $79^{\circ} \mathrm{N}$ (fig. 1), NOV 26 1971. It shows normal faulting on one of two possible fault planes with strike $10^{\circ}$ and dip $52^{\circ} \mathrm{W}$ or strike $63^{\circ}$ and dip $52^{\circ} \mathrm{SE}$ (Sykes \& Sbar 1973).

From the fault plane solutions, minimum and maximum compressive-stress axes consistent with the solution are derived. The fault plane solution in the Arctic Ocean indicates either north-south compression or east-west tension, and the fault plane solution in northeast Greenland indicates tectonic tension SE-NW. The maximum compressive-stress axis of the latter earthquake is almost vertical, so the fault plane solution can not be interpreted in terms of horizontal compression.

\section{Earthquakes and tectonics}

The tectonic stresses that generate the earthquakes in Greenland are caused by broad-scale tectonic motions, while the locations of the earthquakes may also be influenced by the crustal and upper mantle structures. The tectonic motions are (1) plate tectonics and (2) vertical motions of Greenland since the latest ice age. Small scale phenomena like ice motion or rock slides are not expected to cause earthquakes of the size discussed in this paper.

(1) The recent plate-tectonic motion is dominated by the sea floor spreading at the mid ocean ridge, which is seen as a topographic high in the North Atlantic, through Iceland, in the middle of the Norwegian-Greenland Sea, between Spitzbergen and north Greenland (fig. 6) and into the Arctic Ocean, where the topographic high is deeper than the deepest contour line in fig. 6. Most of the mid ocean ridge in fig. 6 is segments of spreading while large transform faults are found around Iceland and Jan Mayen Island (JMI in fig. 1) and in a stepwise pattern in the bend near Station Nord. The exact course of the mid ocean ridge in the bend near Station Nord is not well known (P. R. Vogt personal communication 1980). The sea floor spreading at the mid ocean ridge has been continuous for approximately 60 million years (Talwani \& Eldholm 1977, Herron et al. 1974). The seismicity of the mid ocean ridge zone has been described by Husebye et al. (1975).

The Iceland-Faeroe Ridge crosses the mid ocean ridge. It is the broad elevated area from eastern Greenland, across Iceland and south east across the Faroe Islands, with Tertiary and Quaternary volcanic rocks (fig. 6). In the Greenland Sea the Greenland fracture zone is a less prominent feature which crosses the mid ocean ridge. Its highest area may be distinguished in fig. 


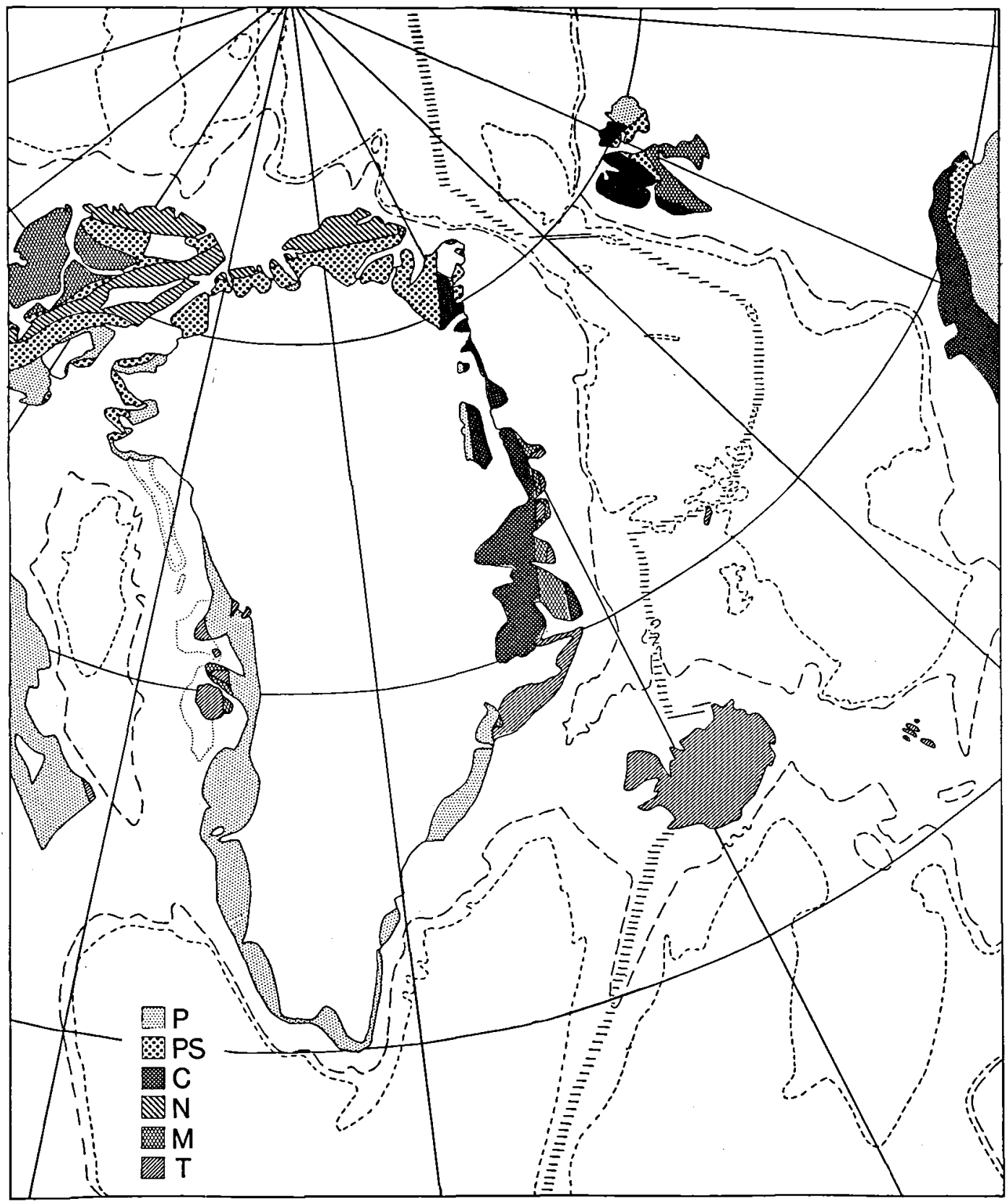

Fig. 6. Generalized geology: P - Precambrian, PS - Proterozoic - Paleozoic sediments, C - Caledonian mountains, N - North Greenland mountains, $M$ - Mesozoic sediments, $T$ - Tertiary and Quaternary volcanics, white areas - ice cap and glaciers as well as sea. Depth contours: Lines of long dashes $-1000 \mathrm{~m}$, lines of short dashes $-2000 \mathrm{~m}$. Lines of small dots outline areas of basalt in the sea. Double line of small dots outline the sediment-filled graben in Melville Bay. Short hatching in the sea - mid ocean ridge. Based on: Egloff \& Johnson 1975, Escher et al. 1970, Escher \& Watt 1976, Grønlie \& Talwani 1977, Henderson 1973 and 1976, Jones et al. 1970, Keen et al. 1972, and Sobczak 1978.

6 around $76^{\circ} \mathrm{N} 0^{\circ} \mathrm{E}$. The only two earthquakes in the deep part of the Greenland Sea, accepted for fig. 1, are located close to that position.

In the Arctic Ocean, in the Norwegian-Green- land Sea, and in the north Atlantic and the Labrador Sea sea floor magnetic anomalies are recognizable, so these deep ocean basins are underlain by oceanic lithosphere, which is geologically 
young close to the mid ocean ridge and older near the continental margins at ocean depths 1000-2000 meters (fig. 6). In Baffin Bay there is a deep area in the middle, and it has been suggested by some authors (Keen et al. 1972, Wetmiller 1974) from marine geophysical evidence and seismic wave propagation that this deep area is underlain by oceanic lithosphere, which developed during the time of sea floor spreading between Greenland and Canada. In the Labrador Sea and possibly in Baffin Bay this occurred between 75 and 40 million years ago (Kristoffersen \& Talwani 1977, Sharma \& Athavale 1975, Srivastava 1978). Qamar (1974) argued that the seismicity of Baffin Bay may be a remnant of the ancient spreading. Fig. 1 in connection with fig. 6 indicates that presently there is almost no seismicity in the middle of the two ocean basins, while most of the earthquake locations are on the Canadian continental margin (Stein et al 1979). On the Greenland continental shelf a sedimentfilled graben structure has been found (Henderson 1976). Its area is outlined by a double-dotted line in fig. 6. Some of the earthquakes in western Greenland (fig. 1) have occurred in or near this Melville Bay Graben.

(2) The interior of Greenland is covered by the ice cap, a remnant from the latest ice age, when nearly all the land areas of fig. 6 were covered with ice. According to Weidick (1976) the ice withdrew from the coastal area between twelve and six thounsand years ago, in eastern and western Greenland, and between eight and six thousand years ago in northern Greenland. The removal of the ice load has caused the coastal area to be isotatically uplifted, up to $140 \mathrm{~m}$. This uplift probably ceased five to six thousand years ago in the southern part of Greenland, while it continued until approximately two thousand years ago in the northern part of Greenland, and it is still continuing in northern Canada. Since the cessation of this isostatic uplift there have been only small sea level changes. Presently western Greenland is claimed to be moving upward since around 1940 (Saxov 1958), while until that time western and eastern Greenland have been moving slowly downward for centuries (Saxov 1958, Egedal 1947, 1953, Nielsen 1952). No measurements are available from northern Greenland on this very recent vertical motion.

Information on the crustal and upper mantle structure in Greenland that might give a part of the explanation of the earthquake locations is limited. No explosion investigations have penetrated the crust. A general classification of crustal and upper mantle structures around the world based on Rayleigh-surface-wave-velocity dispersion was attempted in the 1960 s by Santo (1968). Nearly all of the earth's surface was divided into small regions, each with a characteristic Rayleigh-wave-dispersion curve between wave periods of 20 and 40 seconds, but one area did not fit with any other area, namely Greenland. Santo (1968) guessed correctly that the ice cap of Greenland was the reason, and he suggested that a close study be made of the surface wave dispersion across Greenland. When that was written a close study was already in progress (Gregersen 1970). That study has shown, that the crustal and upper mantle structures in the interior of Greenland is on the average quite similar to the structure of the Canadian Shield. The crustal thickness is only slightly larger than that of the Canadian Shield. No regional differences within Greenland were distinguished.

Locally beneath the seismological stations some crust or upper mantle differences have been observed. The $\mathrm{P}$-wave-arrival-time residuals with reference to world averages are for stations NOR and GDH around zero or minus one second, while for stations Scoresbysund (SCO) and KTG the $\mathbf{P}$ wave residuals are around plus one second or zero (Herrin \& Taggart 1968, Gregersen 1977 , Sengupta \& Julian 1976), i.e. the $P$ waves arrive later at SCO and KTG than at NOR and GDH. Sipkin \& Jordan (1975) suggest, that this indicates an upper mantle structure under KTG, which is more similar to an oceanic structure than to the structure under the other seismic stations. From the surface-wave study of Gregersen (1970) reported above it is clear that only an extremely short part of the path from KTG to GDH could be oceanic structure. SCO and KTG are situated in a Caledonian area, while GDH is in a small area of Precambrian gneiss on Disko, and NOR was on nearly undisturbed Permo-Carboniferous limestone close to the edge of the Caledonian mountain chain (Dawes 1976). According to Larsen (1980) the ocean to continent transition is just off shore near KTG. Four earthquakes in the sea, just north and south of KTG (fig. 1), have occurred near this lithospheric boundary 
Table 2. Seismic refraction results under the Greenland ice cap.

\begin{tabular}{|c|c|c|c|c|c|c|}
\hline Location & $\begin{array}{l}\text { P wave } \\
\text { velocity } \\
\mathrm{km} / \mathrm{s}\end{array}$ & $\begin{array}{c}\text { Thickness } \\
\text { of layer } \\
\text { m }\end{array}$ & $\begin{array}{c}\text { P wave } \\
\text { velocity } \\
\mathrm{km} / \mathrm{s}\end{array}$ & $\begin{array}{c}\text { Thickness } \\
\text { of layer } \\
\text { m }\end{array}$ & $\begin{array}{c}\text { P wave } \\
\text { velocity } \\
\mathrm{km} / \mathrm{s}\end{array}$ & Reference \\
\hline $70^{\circ} \mathrm{N} 50^{\circ} \mathrm{W}$ & 4.8 & 200 & 6.0 & & & Holtzscherer 1953 \\
\hline $70^{\circ} \mathrm{N} 50^{\circ} \mathrm{W}$ & 4.75 & 250 & 6.0 & & & Joset and Holtzscherer 1953 \\
\hline $70^{\circ} \mathrm{N} 48^{\circ} \mathrm{W}$ & 5.0 & 300 & 5.45 & 700 & 6.65 & $\begin{array}{l}\text { Holtzscherer } 1954 \\
\text { Joset and Holtzscherer } 1953\end{array}$ \\
\hline $71^{\circ} \mathrm{N} 40^{\circ} \mathrm{W}$ & 4.7 & thin & 6.2 & & & Brockamp and Kohnen 1965 \\
\hline $77^{\circ} \mathrm{N} 56^{\circ} \mathrm{W}$ & low & 100 & 5.88 & & & Bentley et al. 1957 \\
\hline
\end{tabular}

between oceanic and continental crust and upper mantle structures. In the sea between KTG and the earthquake just south of KTG the sedimentary cover is quite thick. The path between that earthquake and KTG has been used as an example in a surface-wave-dispersion study of wave periods between 2 and 20 seconds (Tatham 1975). An average total thickness of the sedimentary layers was estimated to be between 1.5 and $5.0 \mathrm{~km}$, dependent on assumptions for the physical properties of the sediments.

There is no one to one correlation between the seismicity (fig. 1) and the geology (fig. 6). The southern parts of Greenland and Baffin Island have the Precambrian basement rocks exposed. The ages of these rocks are between 3800 and 1500 million years. It is not known, how large a proportion of the interior of Greenland has Precambrian basement rocks just below the ice cap. There are small areas of Precambrian basement rocks exposed along the ice cap in eastern and in northern Greenland. A few explosion seismic investigations have given the results (table 2) of a few hundred meters of sediment or ground-up rock above a layer with $P$ velocity about $6 \mathrm{~km} / \mathrm{s}$, the velocity of bedrock. A result of Gregersen $(1970)$ is that the bedrock is right under the ice layer, within the resolution of the seismic surface waves, so the average thickness of the sedimentary layers is small under the ice cap. Stewart (1980) has studied the seismic waves, which are reflected from below the earth's surface (PP-waves) in the earth's crust and upper mantle under Greenland. These PP-wave reflections indicate that the interior of Greenland is typical continental shield in contrast to Baffin Bay and the area in eastern Greenland, which is covered by Tertiary basalt, so there is no trace of an upper mantle structure, which could connect the areas of volcanics in eastern and western Greenland (fig. 6). The earthquakes in the Precambrian part of Greenland occur along the southern part of the west coast, and scattered in the interior of southern Greenland.

There is a concentration of earthquakes in Disko, in which Tertiary basalts and Mesozoic sediments meet (fig. 6). Just north of Disko, in Nugssuaq peninsula, sedimentary thicknesses of $21 / 2-3 \mathrm{~km}$ are known from explosion seismic refraction studies (Sharma 1973, Elder 1975).

Along the east coast of Greenland, in Spitzbergen and along the Norwegian west coast there is the Caledonian mountain chain, the two sides of which have been separated by the sea floor spreading in the Norwegian-Greenland Sea (fig. 6). In eastern Greenland a sedimentary graben was formed by rifting already in the Mesozoic (Surlyk 1978). Only one earthquake has been located in or near the sedimentary graben (fig. 1) in addition to the swarm of earthquakes at $73 \frac{1}{2} 2^{\circ} \mathrm{N}$ $20^{\circ} \mathrm{W}$, mentioned previously in this paper and by Gregersen (1979).

The earthquakes in north eastern Greenland occur, where the coastline crosses the Caledonian mountain chain. This longitutinal zone of earthquakes looks like an extension of the spreading plate boundary from the Arctic Ocean into the Greenland plate (fig. 1). The only fault plane solution available in north eastern Greenland can be interpreted in support of this idea as normal faulting on a fault with strike almost along the seismicity zone. We will have to wait for other large earthquakes, for which fault plane solutions can be determined, to see whether the one fault plane solution is typical for the area.

Along the north coast of Greenland there is a continuation of the mountain chain of northern Canada (fig. 6). Its age is Devonian/Carbonife- 
rous. Dawes (1976) has shown that the older sediments south of the mountains are dipping northward under the mountain chain. The earthquakes in northern Greenland occur mainly in the mountain chain. It looks (fig. 1) as if the seismic zone in northern Greenland is an extension of the plate boundary between Station Nord and Spitzbergen into the Greenland plate. The strike-slip fault plane solution of fig. 5 showed the two possible fault planes along and perpendicular to the spreading mid ocean ridge in the Arctic Ocean. If the shearing is on the plane perpendicular to the ridge it is right lateral. Like for the other fault plane solution we will have to wait for more sufficiently large earthquakes to see whether this fault plane solution is typical for the northern Greenland area.

Presently it is not possible to distinguish whether recent plate tectonics motions or isostatic uplift is the main cause of the intraplate earthquakes in Greenland. The same doubt is discussed for the Scandinavian intraplate earthquakes (Husebye et al. 1978, Båth 1979). Many more accurate earthquake locations and focal mechanisms are needed.

Since the two areas of most concentrated seismicity are in north eastern and in northern Greenland it is suggested in this paper that the bend of the plate boundary near Station Nord is connected with some stretching and shearing near the bend, and that this is the cause of the earthquakes. The two available fault plane solutions are in agreement with this suggestion.

Recently it has been proposed that isostatic uplift is important for some earthquakes (Gregersen 1979). It was demonstrated that along the continental margins of Greenland, Norway and northern Canada earthquake swarms have occurred. The common swarm features were proposed to have a common cause. Common to these continental areas is that their interiors, when Greenland and Canada are taken as one unit, are presently uplifted at rates of $1-2 \mathrm{~cm}$ per year, while the directions of the recent platetectonics movement in the oceans by the three involved continental margins are quite different (Gregersen 1979).

\section{Dansk sammendrag}

Data om jordskælv i Grønland fra internationale og canadiske seismologiske bulletiner er blevet sammenholdt med seismogrammer fra de seismologiske stationer i Grønland, og nogle få nye jordskælv er desuden blevet lokaliseret ud fra seismogrammer fra Grønland og Canada. Ialt er 103 troværdige jordskælv blevet bekræftet, beregnet eller genberegnet. Jordskælvene foregår hovedsagelig langs med kysterne i Øst-, Nord- og Vestgrønland. De største jordskælv i Grønland har Richtertal cirka 5. Der er ingen tektonisk pladegrænse i Grønland. "Intraplate"-jordskælvszonerne i Nordøst- og Nordgrønland ser ud til at være fortsættelser af pladegrænserne ved knækket på midtoceanryggen nær Station Nord, mellem Spitzbergen og Grønland.

Under Indlandsisen er der kun sket få jordskælv. I Øst- og Nordgrønland har der fundet nogle få jordskælvssværme sted. I Vestgrønland er der bemærket en række seismiske signaler i en afstand af $175 \mathrm{~km}$ fra Godhavn. De kunne skyldes jordskælv. Tidsfølgen af jordskælvene i Grønland viser to tidsintervaller med forøget seismisk aktivitet efter de to største jordskælv. Det tyder på, at spændingsudløsningerne $i$ de største jordskalv har en forbindelse med spændingsudløsningerne $\mathrm{i}$ de mindre jordskælv i mere end $1000 \mathrm{~km}$ 's afstand $i$ andre dele af Grønland. Der er kun en begrænset korrelation mellem jordskælvsaktiviteten og geologien. Det kan ikke afgøres om hovedårsagen til Grønlands "intraplate"-jordskælv er isostatisk landhævning efter den sidste istid eller tektonisk pladebevægelse $\mathbf{i}$ forbindelse med havbundsspredningen i Norskeog Grønlandshavet og i det Arktiske Ocean.

Acknowledgments. Assistance by H. P. Rasmussen in handling seismograms and in finding new earthquakes is greatly appreciated. The seismograms and the reports on felt earthquakes are from files in the Danish Geodetic Institute. Thanks are due to J. Hjelme, E. Hjortenberg, H. C. Larsen, and T. F. D. Nielsen for their suggestions concerning the manuscript and to L. Monrad for drafting the figures and typing the text.

\section{References}

Barazangi, M. \& Dorman, J. 1969: World seismicity maps compiled from ESSA, Coast and Geodetic Survey, epicenter data, 1961-1967. Bull. Seism. Soc. Am. 59: 369-380. 
Basham, P. W., Forsyth, D. A. \& Wetmiller, R. J. 1977 a: The seismicity of northern Canada. Can J. Earth Sci. 14: 1646-1667.

Basham, P. W., Horner, R. B., Wetmiller, R. J., Stevens, A. E. \& Leblanc, G. 1977 b: Canadian earthquakes - 1972. Earth Phys. Br. Seism. Ser. no. 76: 48 p.

Bentley, C. R., Pomeroy, P. W. \& Dorman, H. J. 1957: Seismic measurements on the Greenland ice cap. Part I: Studies at $76^{\circ} 59^{\prime} \mathrm{N} 56^{\circ} 05^{\prime} \mathrm{W}$. Ann. Geophysique 13: 253-275.

Brockamp, B. \& Kohnen, H. 1965: Ein Beitrag zu den seismischen Untersuchungen auf dem Grönländischen Inlandeis. Polarforschung 35: 2-12.

Båth. M. 1979: Svenska jordskälv i ny belysning in Tvärvetenskapliga geoprojektet, bidrag vid sammankomst $i$ Kungliga Tekniska Högskolan 6 FEB 1979 (ed. A. Bjerhammar).

Dawes, P. R. 1976: Precambrian to Tertiary of northern Greenland in Escher, A. \& Watt, W. S.: Geology of Greenland. Geological Survey of Greenland. 248-303.

Egedal, J. 1947: The sinking of Greenland. Meddr om Grønland 134, 7: 1 - 6 .

Egedal, J. 1953: Tidal observations in Greenland in the years 1934-1951. Appendix to the Nautical-meteorological annual 1952, Danish Meteorological Institute, G.E.C. Gad, Copenhagen.

Egloff, J. \& Johnson, G. L. 1975: Morphology and Structure of the Southern Labrador Sea. Can. J. Earth Sci. 12: 2111-2133.

Elder, J. W. 1975: A seismic and gravity study of the western part of the Cretaceous-Tertiary sedimentary basin of central West Greenland. Rapp. Grønlands geol. Unders. 69 : 5-9.

Escher, A., Henriksen, N., Dawes, P. R. \& Weidick, A. 1970: Tectonic/Geological Map of Greenland. Geological Survey of Greenland.

Escher, A. \& Watt, W. S. 1976: Geology of Greenland. Geological Survey of Greenland. $603 \mathrm{pp}$.

Forsyth, D. 1973: Compressive stress between two mid-ocean ridges. Nature 243: 78-79.

Giesecke, K. L. 1910: Mineralogisches Reisejournal über Grönland 1806-13. Meddr om Grønland 35 (in German).

Glahn, H. C. 1921: Missionær i Grønland, Diary 1763-64, 1766-67 and 1767-68. Grønlandske Selskabs skrifter IV, G.E.C. Gad, Copenhagen (in Danish).

Gregersen, S. 1970: Surface wave dispersion and crustal structure in Greenland. Geophys. J. Roy. astr. Soc. 22: 29-39.

Gregersen, S. 1977: P. wave travel time residuals caused by a dipping plate in the Aegean Arc in Greece. Tectonophysics 37: 83-93.

Gregersen, S. 1979: Intraplate earthquake swarms in Greenland and adjacent continental regions. Nature 281: 661-662.

Gregersen, S. (in press) Seismicity and observations of $\mathrm{Lg}$ wave attenuation in Greenland. Tectonophysics.

Grønlie, G. \& Talwani, M. 1977: Bathymetry of the Norwegian-Greenland Seas. Printed by Emil Moestue A/S, Oslo, Norway.

Harboe, E. G. 1910: Meddelelser om jordskælv og vulkanudbrud. Bull. geol. Soc. Denmark 3: 377-392 (in Danish).

Harboe, E. G. 1915: Meddelelser om jordskælv og vulkanudbrud i Danmark med bilande i tidsrummet 1909-1913. Bull. geol. Soc. Denmark 4: 395-427 (in Danish).

Henderson, G. 1973: The Implications of Continental Drift for the Petroleum Prospects of West Greenland, in Implications of Continental Drift to Earth Sciences vol. 1 (ed. Tarling \& Runcorn). Academic Press: 599-608.

Henderson, G. 1976: Petroleum geology in Geology of Greenland (ed. Escher, A. \& Watt, W. S.), Geological Survey of Greenland. 488-505.
Herrin, E. \& Taggart, J. 1968: Regional variations in $P$ travel times. Bull. Seism. Soc. Am. 58: 1325-1337.

Herron, E. M., Dewey, J. F. \& Pitman III, W. C. 1974: Plate tectonics model for the evolution of the Arctic. Geology 2: 377-380.

Hodgson, J. H., Båth, M., Jensen, H., Kvale, A., Linden, N. A., Murphy, L. M., Shebalin, N. V., Tryggvason, E \& Vesanen, E. 1965: Seismicity of the Arctic. Ann. Int. Geophys. Year 30: 33-66.

Holtzscherer, J.-J. 1965: Mesures seismiques in Contribution a la Connaissance de l'Inlandsis du Groenland, Expedition Polaires Francaises, Paris (in French).

Horner, R. B., Milne, W. G. \& McMechan, G. A. 1974: Canadian earthquakes - 1969. Earth Phys. Br. Seism. Ser. no. 67: $44 \mathrm{p}$.

Horner, R. B., Milne, W. G. \& McMechan, G. A. 1975: Canadian earthquakes - 1970. Earth Phys. Br. Seism. Ser, no. 69: 43 p.

Horner, R. B., Milne, W. G. \& McMechan, G. A. 1976: Candian earthquakes - 1971. Earth Phys. Br. Seism. Ser. no. 74: $45 \mathrm{p}$.

Horner, R. B., Stevens, A. E. \& Wetmiller, R. J. 1979 a: Canadian Earthquakes - 1977. Earth Phys. Br. Seism. Ser. no. 81: $58 \mathrm{p}$.

Horner, R. B., Stevens, A. E. \& Wetmiller, R. J., 1979b: Canadian Earthquakes - 1978. Earth Phys. Br. Seism. Ser. no. 83: $54 \mathrm{p}$.

Husebye, E. S., Bungum, H., Fyen, J. \& Gjøystdal, H. 1978: Earthquake activity in Fennoscandia between 1497 and 1975 and intraplate tectonics. Norsk Geologisk Tidsskrift 58: 51-68.

Husebye, E. S., Gjøystdal, H., Bungum, H. \& Eldholm, O. 1975: The seismicity of the Norwegian and Greenland Seas and adjacent continental shelf areas. Tectonophysics 26: 55-70.

Jones, E. J. W., Ewing, M., Ewing, J. I. \& Eittreim, S. L. 1970: Influences of Norwegian Sea Overflow Water on Sedimentation in the North Atlantic and Labrador Sea. $J$. Geophys. Res. 75: 1655-1680.

Joset, A. \& Holtzscherer, J.-J. 1953: Etude des vitesses de propagation des ondes séismiques sur l'Inlandsis du Groenland. Ann. Geophysique. 9: 330-344 (in French).

Keen, C. E., Barrett, D. L., Manchester, K. S. \& Ross, D. I. 1972: Geophysical Studies in Baffin Bay and Some Tectonic Implications. Can. J. Earth Sci. 9: 239-256.

Klein, F. W., Einarsson, P. \& Wyss, M. 1973: Microearthquakes on the Mid-Atlantic plate boundary on the Reykjanes peninsula in Iceland. J. Geophys. Res. 78: 5084-5099.

Kristoffersen, Y. \& Talwani, M. 1977: Extinct triple junction south of Greenland and the Tertiary motion of Greenland relative to North America. Geol. Soc. Am. Bull. 88: 1037-1049.

Larsen, H. C. 1980: Geological perspectives of the East Greenland continental margin. Bull. geol. Soc. Denmark 29: 77-101.

Linden, N. A. 1961: Seismicity of the Arctic region. Ann. Int. Geophys. Year 11: 375-387.

Nielsen, E. W. 1952: A determination of the subsidence of the land at Angmagssalik. Meddr om Gronland 136, 2: 3-12.

Petersen, J. \& Rosing, C. 1905: Beretninger om jordrystelserne ved Angmagssalik i Øst-Grønland i 1904 og 1905. Bull. geol. Soc. Denmark 2 no. 11: 109-112 (in Danish).

Qamar, A. 1974: Seismicity of the Baffin Bay region. Bull. Seism. Soc. Am. 64: 87-98.

Raben, F. C. 1826: Udtog af en dagbog holdet på en rejse i Grønland i sommeren 1823 (slutning). Tidsskrift for Naturvidenskaberne no. 10, volume 4: 1-35 (in Danish).

Rüttel, F. C. P. 1917: Ti àr blandt Østgrønlands hedninger. Gyldendal. Copenhagen (in Danish). 
Santo, T. 1968: Lateral variation of Rayleigh wave dispersion character. Part V. North American continent and Arctic Ocean. Bull. Earthq. Res. Inst. 46: 431-456.

Saxov, S. 1958: The uplift of western Greenland. Bull. geol. Soc. Denmark 13: 518-523.

Sengupta, M. K. \& Julian, B. R. 1976: P-wave travel times from deep earthquakes. Bull. Seism. Soc. Am. 66: 1555-1579.

Sharma, P. V. 1973: Seismic velocity and sediment thickness investigations by refraction soundings in Nûgssuaq, West Greenland. Geological Survey of Greenland Rapp. 54, 22 pp.

Sharma, P. V. \& Athavale, R. N. 1975: Palaeomagnetic evidence relating to the Cenozoic drift of Greenland. Tectonophysics 29: 209-221.

Sipkin, S. A. \& Jordan, T. H. 1975: Lateral heterogeneity of the upper mantle determined from the travel times of ScS. J. Geophys. Res. 80: 1474-1484.

Sobczak, L. W. 1978. Arctic Bathymetry in Arctic Geophysical review (ed. J. F. Sweeney). Publ. Earth. Phys. Br. 45, no. 4: 7-14.

Srivastava, S. P. 1978. Evolution of the Labrador Sea and its bearing on the early evolution of the North Atlantic. Geophys, J. Roy. astr. Soc. 52: 313-357.

Stein, S., Sleep, N. H., Gjeller, R. J., Wang, S.-C. \& Kroeger, G. C. 1979: Earthquakes along the passive margin of Eastern Canada. Geophys. Res. Lett. 6: 537-540.

Stevens, A. E., Milne, W. G., Horner, R. B., Wetmiller, R. J., Leblanc, G. \& McMechan, G. A. 1976: Canadian earthquakes - 1968. Earth Phys. Br. Seism. Ser. no. 71: 39 p.

Stevens, A. E., Milne, W. G., Wetmiller, R. J. \& Horner, R. B. 1972: Canadian earthquakes - 1976. Earth Phys. Br. Seism. Ser. no. 62: 55 p.

Stevens, A. E., Milne, W. G., Wetmiller, R. J. \& Leblanc, G. 1973: Canadian earthquakes - 1967. Earth Phys. Br. Seism. Ser. no. 65: 65 p.

Stewart, I. C. F. 1980: Arctic lithospheric structure from delays of teleseismic P-wave reflections. Tectonophysics 69: 37-62.
Surlyk, F. 1978: Jurassic basin evolution of East Greenland. Nature 274: 130-133.

Sykes, L. R. 1965: The seismicity of the Arctic. Bull. Seism. Soc. Am. 55: 501-517.

Sykes, L. R. \& Sbar, M. L. 1973: Intraplate earthquakes, lithospheric stresses and the driving mechanism of plate tectonics. Nature 245: 298-302.

Talwani, M. \& Eldholm, O. 1977: Evolution of the Norwegian-Greenland Sea. Geol. Soc. Am. Bull. 88: 969-999.

Tatham, R. H. 1975: Surface-wave dispersion applied to the detection of sedimentary basins. Geophysics 40: 40-55.

Vogt, P. R. 1978: Long-wavelength gravity anomalies and intraplate seismicity. Earth Planet. Sci. Lett. 37: 465-475.

Voronov, P. S. \& Klushin, I. G. 1963: On the aseismicity of Antarctica and Greenland. Morskoj Transport 12: 5-13 (in Russian).

Weidick, A. 1976: Glaciation and the Quaternary of Greenland, in Geology of Greenland (ed. Escher, A. \& Watt, W. S.), Geological Survey of Greenland. 430-458.

Wetmiller, R. J. 1974: Crustal structure of Baffin Bay from the earthquake-generated Lg phase. Can. J. Earth Sci. 11: 123-130.

Wetmiller, R. J. 1976a: Canadian earthquakes - 1973. Earth Phys. Br. Seism. Ser. no. 72: 51 p.

Wetmiller, R. J. 1976b: Canadian earthquakes - 1974. Earth Phys. Br. Seism. Ser. no. 73: $62 \mathrm{p}$.

Wetmiller, R. J. 1977: Canadian earthquakes - 1975. Earth Phys. Br. Seism. Ser no. 77: $71 \mathrm{p}$.

Wetmiller, R. J. \& Forsyth, D. A. 1978: Seismicity of the Arctic, 1908-1975 in Arctic geophysical review (ed. J. F. Sweeney). Publ. Earth Phys. Br. 45 no. 4: 15-24.

Wetmiller, R. J. \& Forsyth, D. A. 1982: Review of seismicity and other geophysical data near Nares Strait, in Nares Strait and the drift of Greenland: a conflict in plate tectonics. (ed. Dawes, P. R. \& Kerr, J. W.), Meddr. Gronland 8: 261-274.

Wetmiller, R. J. \& Horner, R. B. 1978: Canadian earthquakes - 1976. Earth Phys. Br. Seism. Ser. no. 79: 75 p. 